\title{
ACCUMULATION AND TEMPERATURE MEASUREMENTS ON THE JAMES ROSS ISLAND ICE CAP, ANTARCTIC PENINSULA, ANTARCTICA
}

\author{
By A.J. Aristarain, \\ (Instituto Antártico Argentino and Consejo Nacional de Investigaciones \\ Científicas y Técnicas, 5500 Mendoza, Argentina) \\ J.F. Pinglot, and M. POURChet
}

(Laboratoire de Glaciologie et Géophysique de l'Environnement, Centre National de la Recherche

Scientifique, 38402 Saint-Martin-d'Hères Cedex, France)

\begin{abstract}
Basic glaciological measurements from the James Ross Island ice cap are presented, including mean annual accumulation and firn temperature. In addition to the well-known radioactivity levels of January 1955 and 1965 in Antarctic snow, two new radioactivity levels corresponding to January 1969 and January 1974 are used in determining the accumulation values. The measurements reveal certain climatic features of this ice cap.
\end{abstract}

\section{INTRODUCTION}

James Ross Island (lat. $64^{\circ} \mathrm{S}$, long. $58^{\circ} \mathrm{W}$.) is located off the northern end of the Antarctic Peninsula. The island itself has a diameter of about $50 \mathrm{~km}$, and it is completely covered by an ice cap with a central elevation of $1690 \mathrm{~m}$ and an estimated thickness of about $300 \mathrm{~m}$ (Aristarain, 1980).

In four successive field programs conducted during summer seasons 1976-78-79 and 1981, 17 shallow cores (with depths ranging from 8 to $31 \mathrm{~m}$ ) were drilled in the central part of the island (Fig. 1), working from a base camp sited at Dalinger Dome.

Snow sampling was accompanied by other routine measurements: topographical surveys, elevations, $10 \mathrm{~m}$ depth snow temperatures, and sample densities.

The ice cores were analysed for global beta radioactivity. These results were used to determine the mean annual accumulation for each location.

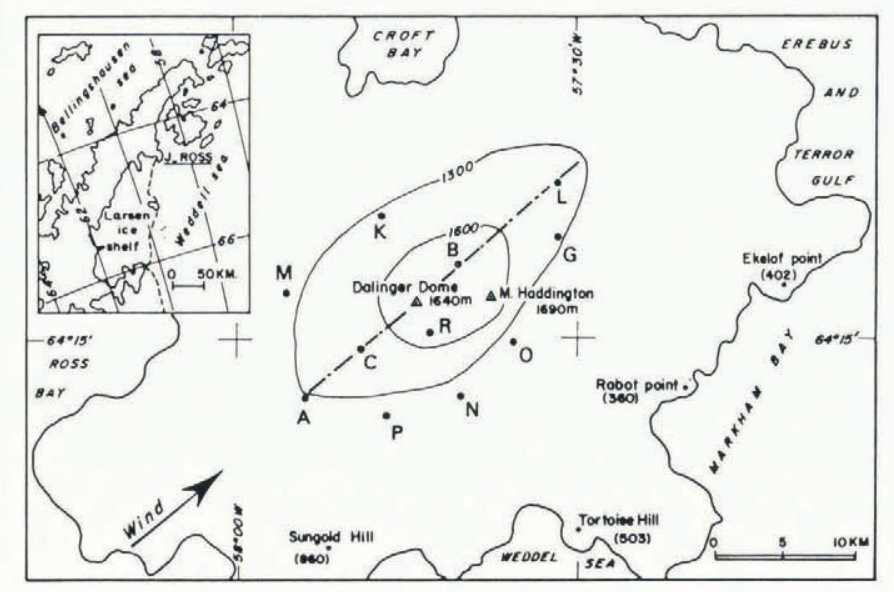

Fig. 1. Map of James Ross Island (British Antarctic Survey, 1974) showing sampling stations.

\section{EXPERIMENTAL CONDITIONS}

The elevation determined for Dalinger Dome $(1640 \mathrm{~m})$ is the final result of a large number of barometric surveys conducted between this location and Vice Commodore Marambio Station, located about $50 \mathrm{~km}$ away.

From other simultaneous barometric surveys, we have determined the relative elevations of the other stations on James Ross Island with respect to Dalinger Dome.

The in-situ temperature measurements were made in 10-14 m depth bore holes either using a conventional thermometer or, more often, a set of calibrated thermistors (absolute accuracy: $\pm 0.1^{\circ} \mathrm{C}$ ). Two temperature profiles, covering the first $20 \mathrm{~m}$ were measured during one summer (Fig. 2), enabling us to calculate the vertical gradient of the in-depth temperature around the $10 \mathrm{~m}$ depth level, and to correct all the temperatures to $10 \mathrm{~m}$ depth (Table I).

The radio-isotopes were extracted from the snow samples using ion-exchange filters (Delmas and Pourchet, 1977) and then measured with our low-level beta-counting equipment (Pinglot and Pourchet, 1979).

\section{DATING}

Over the last 30 years, atmospheric thermonuclear tests have injected great amounts of artificial radio-isotopes into the stratosphere. They have since been deposited in the

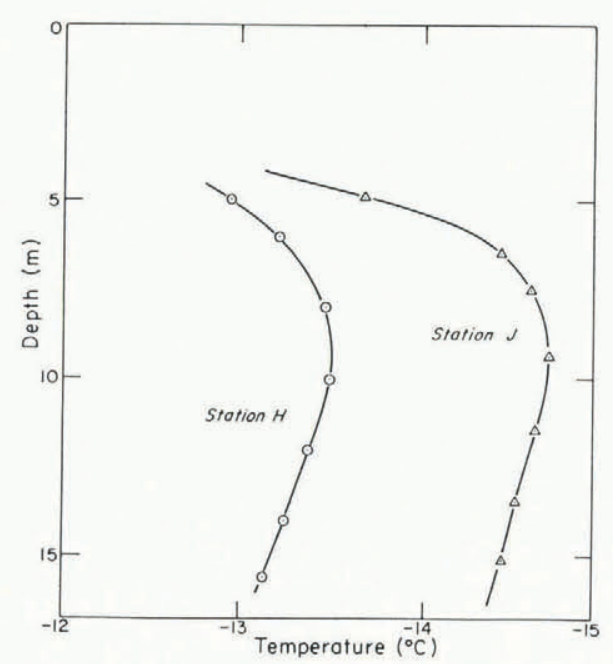

Fig. 2. Snow temperature versus depth for stations $H$ and $J$. These measurements were made during the summer season. 
snow, giving rise to radioactivity levels currently used to date the corresponding snow layers.

In Antarctica, the two levels most of ten used as a chronological base are January 1955 (Picciotto and Wilgain, 1963) and January 1965 (Crozaz, 1969).

For all the 15 stations involved in radio-isotope measurements (Table I), the snow cores were continuously divided into a large number of $10 \mathrm{~cm}$ samples to ensure an accurate temporal resolution. This has allowed us to distinguish the austral summer radioactivity references, as artificial radio-isotopes arrive in Antarctica during this season of the year (Lambert and others, 1977).

Each detailed radioactivity profile has been smoothed to assist in interpreting the general trends of the curves. Moreover, the accuracy of the measurements is lower for samples corresponding to depths of weak specific radioactivity, i.e. for depths between the surface and January 1965.

\section{DALINGER DOME STATIONS}

At station D (Fig. 3), Aristarain and others (1986) have determined each single summer season since 1955 using both artificial radioactivity and stable-isotope stratigraphy. Located at the center of our study area, this station represents an excellent reference location for accumulation determinations. On the radioactivity profile, the peak corresponding to January 1955 (marked 1 in Figure 3) is poorly defined and does not offer a clear reference level. We have observed this same phenomenon at many coastal stations, questioning its general acceptance as a key chronological indicator.

The 1965 radioactivity peak (marked 2 in Figure 3 ) is well marked, lasting 5 years and showing an increase in radioactivity as early as January 1965 , a maximum in January 1966, and then a continuous decrease over 3 years. This depletion is due to the draining of the stratospheric reservoir during the nuclear moratorium extending from December 1962 to May 1966 (Pourchet and others, 1983). This decrease ceased with the commencement of further atmospheric thermonuclear tests by China in June 1967 and by France in July 1968. Due to delay in the radio-isotope transport, the next increase in the radioactivity of Antarctic snow occurs in January 1969 (marked 3 in Figure 3).

Such a phenomenon also occurs in January 1974 (marked 4 in Figure 3 ). On the smoothed curve, these last

TABLE I. ALTITUDE, TEMPERATURE, AND ACCUMULATION FOR 17 STATIONS ON THE JAMES ROSS ISLAND ICE CAP

\begin{tabular}{|c|c|c|c|c|c|c|c|c|c|c|c|}
\hline Station & Altitude & $\begin{array}{l}10 \mathrm{~m} \text { temp. } \\
\left({ }^{\circ} \mathrm{C}\right) \text { and } \\
\text { depth of } \\
\text { measurement } \\
(\mathrm{m})\end{array}$ & $\begin{array}{l}\text { Date of } \\
\text { drilling }\end{array}$ & \multicolumn{3}{|c|}{$\begin{array}{l}\text { Depth }(\mathrm{cm}) \text { of beta horizons and } \\
\text { cumulative density }\left(\mathrm{Mg} \mathrm{m}^{-3}\right)\end{array}$} & Jan 1974 & \multicolumn{3}{|c|}{$\begin{array}{c}\text { Mean accumulation }\left(\mathrm{g} \mathrm{cm}^{-2} \mathrm{a}^{-1}\right) \\
\text { Beta radioactivity }\end{array}$} & $\begin{array}{l}\text { Snow stake } \\
\text { Average } \\
2 \text { years }\end{array}$ \\
\hline $\begin{array}{l}\text { Dalinger } \\
\text { Dome }\end{array}$ & & $\begin{array}{l}-14.3 \\
(14 \mathrm{~m})\end{array}$ & Mar 1979 & $\begin{array}{r}2142 \\
(0.539)\end{array}$ & $\begin{array}{r}1500 \\
(0.533)\end{array}$ & $\begin{array}{c}1180 \\
(0.518)\end{array}$ & $\begin{array}{l}650 \\
(0.487)\end{array}$ & 35.5 & 57.1 & 61.1 & 47.0 \\
\hline $\mathbf{J}$ & 1640 & $\begin{array}{l}-14.7 \\
(11 \mathrm{~m})\end{array}$ & Mar 1981 & & $\begin{array}{c}1777 \\
(0.544)\end{array}$ & $\begin{array}{c}1410 \\
(0.529)\end{array}$ & $\begin{array}{l}927 \\
(0.504)\end{array}$ & & 60.4 & 62.1 & \\
\hline 154 & & & Mar 1981 & $\begin{array}{c}2420 \\
(0.568)\end{array}$ & $\begin{array}{r}1759 \\
(0.544)\end{array}$ & & & 41.8 & 59.8 & & \\
\hline A & 1310 & $\begin{array}{l}-13.1 \\
(14 \mathrm{~m})\end{array}$ & Jan 1979 & & & & $\begin{array}{l}860 \\
(0.503)\end{array}$ & & & 86.5 & \\
\hline M & 1280 & $\begin{array}{l}-12.7 \\
(10 \mathrm{~m})\end{array}$ & Mar 1981 & & & & $\begin{array}{c}711 \\
(0.490)\end{array}$ & & & 49.8 & \\
\hline$N$ & 1240 & $\begin{array}{l}-11.8 \\
(12 \mathrm{~m})\end{array}$ & Mar 1981 & & & & $\begin{array}{l}880 \\
(0.501)\end{array}$ & & & 63.0 & \\
\hline 0 & 1190 & $\begin{array}{l}-11.3 \\
(12 \mathrm{~m})\end{array}$ & Mar 1981 & & & $\begin{array}{l}1110 \\
(0.514)\end{array}$ & $\begin{array}{l}540 \\
(0.474)\end{array}$ & & & 47.5 & \\
\hline Mount & & $\begin{array}{l}-12.9 \\
(10 \mathrm{~m})\end{array}$ & Jan 1976 & $\begin{array}{c}575 \\
(0.512)\end{array}$ & $\begin{array}{c}268 \\
(0.500)\end{array}$ & & & 14.0 & 12.2 & & \\
\hline $\begin{array}{r}\mathrm{F} \\
\text { Haddington }\end{array}$ & 1690 & $\begin{array}{l}-13.4 \\
(14 \mathrm{~m})\end{array}$ & Mar 1979 & $\begin{array}{c}757 \\
(0.518)\end{array}$ & $\begin{array}{c}385 \\
(0.500)\end{array}$ & & & 20.0 & 13.7 & & \\
\hline $\mathrm{H}$ & & $\begin{array}{l}-13.5 \\
(12 \mathrm{~m})\end{array}$ & Apr 1981 & & & & & & & & $14.6^{(1)}$ \\
\hline L & 1375 & & Mar 1981 & & $\begin{array}{c}633 \\
(0.522)\end{array}$ & $\begin{array}{c}393 \\
(0.498)\end{array}$ & & & 20.6 & & \\
\hline G & $\begin{array}{c}1350 \\
\text { (estimated) }\end{array}$ & $\begin{array}{l}-11.3 \\
(14 \mathrm{~m})\end{array}$ & Mar 1979 & $\begin{array}{c}1030 \\
(0.550)\end{array}$ & $\begin{array}{c}705 \\
(0.528)\end{array}$ & $\begin{array}{c}500 \\
(0.510)\end{array}$ & $\begin{array}{l}325 \\
(0.489)\end{array}$ & 19.4 & 26.6 & 25.5 & 10.8 \\
\hline C & 1460 & $\begin{array}{l}-13.8 \\
(14 \mathrm{~m})\end{array}$ & Apr 1979 & & & & $\begin{array}{l}750 \\
(0.484)\end{array}$ & & & 72.6 & 62.3 \\
\hline $\mathrm{P}$ & 1220 & $\begin{array}{l}-11.2 \\
(12 \mathrm{~m})\end{array}$ & Apr 1981 & & & & $\begin{array}{c}813 \\
(0.496)\end{array}$ & & & 57.6 & \\
\hline K & 1330 & $\begin{array}{l}-12.2 \\
(12 \mathrm{~m})\end{array}$ & Mar 1981 & & & $\begin{array}{c}1137 \\
(0.515)\end{array}$ & $\begin{array}{c}446 \\
(0.464)\end{array}$ & & & 48.8 & \\
\hline $\mathrm{R}$ & 1610 & $\begin{array}{l}-14.1 \\
(11 \mathrm{~m})\end{array}$ & Apr 1981 & & & $\begin{array}{c}1018 \\
(0.549)\end{array}$ & & & & 46.6 & \\
\hline B & $\begin{array}{c}1630 \\
\text { (estimated) }\end{array}$ & $\begin{array}{l}-14.2 \\
(10 \mathrm{~m})\end{array}$ & Dec 1977 & & $\begin{array}{c}985 \\
(0.498)\end{array}$ & $\begin{array}{c}620 \\
(0.468)\end{array}$ & & & 37.7 & 32.2 & \\
\hline
\end{tabular}

(1) 5 years at $\mathrm{H}$

(2) Determined for the greatest lapse of time. 


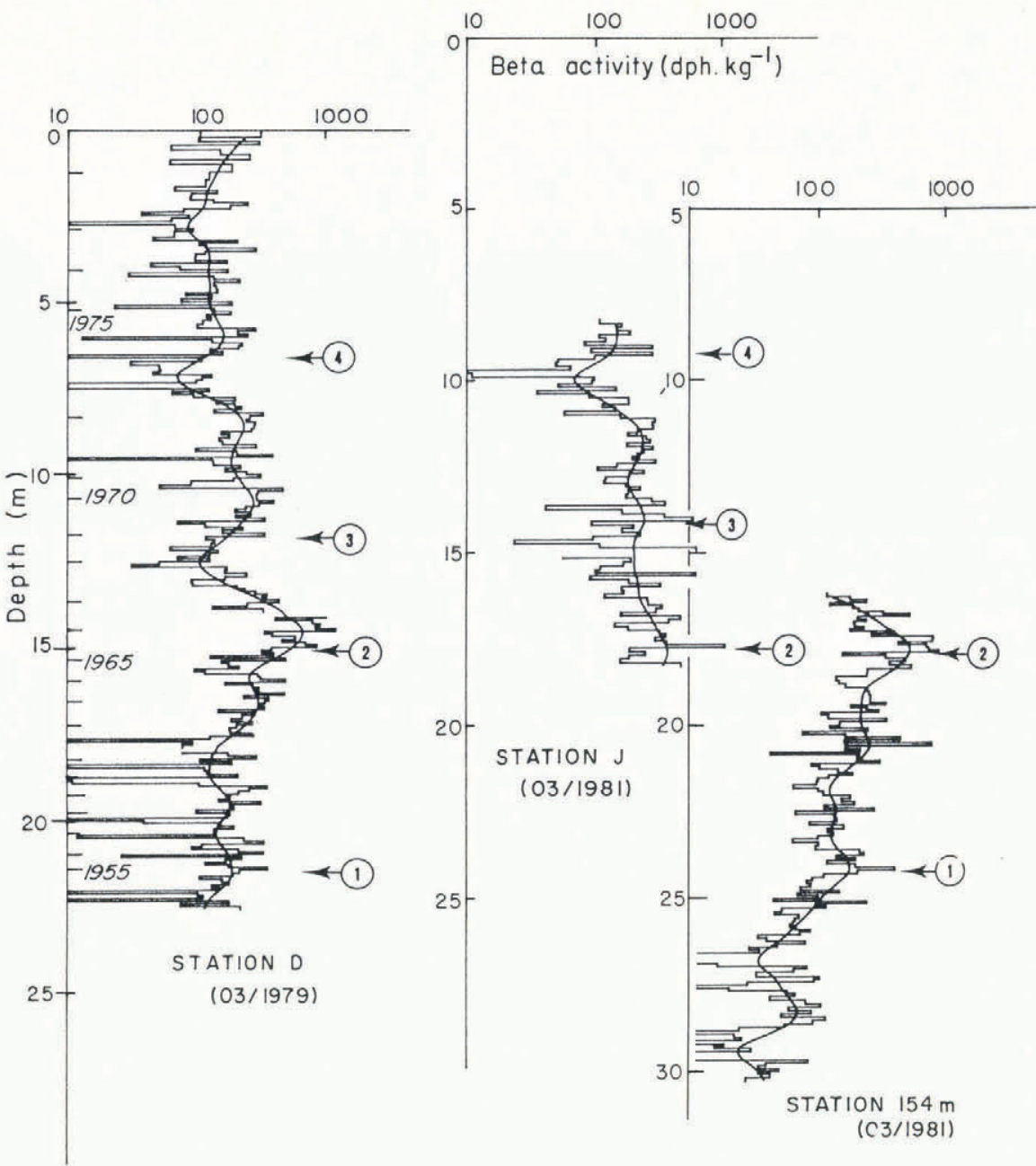

Fig. 3. Beta-radioactivity versus depth for our reference station. The indices correspond to the radioactivity levels used to date the entire set of stations.

1. January 1955; 2, January 1965; 3, January 1969; 4, January 1974.

The isotope-stratigraphy dates are given for station $D$.

two events (marked 3 and 4 in Figure 3 ) are clearly defined, the slope of these somewhat lower peaks being greater than the slope of the moratorium decreasing curve, after the January 1965 peak. These events thus provide two further well-defined chronological levels.

We have also plotted (Fig. 3) the profiles for stations J and "154", located $290 \mathrm{~m}$ from station D. These profiles present general trends which are similar to those of station $D$, indicating a uniform stratigraphic pattern throughout the Dalinger Dome area.

For station B (Aristarain and Delmas, 1981), dating by use of the beta radioactivity curve alone is difficult. A tentative interpretation led to defining the 1965 and 1969 levels.

\section{Stations $A, M, N$, and $O$}

For these stations (Fig. 4), we observed similar overall trends as well as close mean values for the radioactivity at the different known levels. Although the minimum of the curve established for the period before the 1974 secondary peak is sometimes less marked than at station D (stations O and $\mathrm{N}$ ), the maximum value for this peak is especially uniform: $282 \mathrm{dph} \mathrm{kg}^{-1}$ for station D, and 243, 300, 260, and $285 \mathrm{dph} \mathrm{kg}^{-1}$ for stations $\mathrm{A}, \mathrm{M}, \mathrm{N}$, and $\mathrm{O}$, respectively.

\section{Stations $F, G, H$, and $L$}

The general trend of the beta-radioactivity curves is very similar for these four stations (Fig. 5). The measured accumulation is low. Stations $\mathrm{H}$ and $\mathrm{F}$ are very close to Mount Haddington, the highest point on James Ross Island $(1690 \mathrm{~m})$. For these locations, the low accumulation value has been confirmed by stake measurements.
Moreover, the radioactivity level corresponding to January 1955 (marked 1 in Figure 5), while not as high as in central Antarctic stations such as Dome C (Petit and others, 1982) or South Pole (Pourchet and others, 1983), is still well marked.

The main feature leading to these similarities with the radioactivity curves from the East Antarctic plateau is the low accumulation rate and it is independent of a coastal or continental location, for stations $\mathrm{F}, \mathrm{G}, \mathrm{H}$, and $\mathrm{L}$.

\section{Stations $C, P, K$, and $R$}

This set of curves (Fig. 6) shows a poorer fit with respect to the Dalinger Dome curve than those of the preceding locations. However, we can confirm that the January 1965 level (marked 2 in Figure 6) is never reached, due to the shallow depth of the drilling; and at least one of the more recent levels, i.e. either January 1969 (marked 3 in Figure 6) or January 1974 (marked 4 in Figure 6), shows up reasonably well in each case. For station $C$, the accumulation value deduced from the radioactivity profile has been confirmed by stake measurements.

\section{INTERPRETATION}

1. The snow-accumulation rates relate to that part of the island with an altitude greater than $1190 \mathrm{~m}$. Over this area, the firn temperature is sufficiently below $0^{\circ} \mathrm{C}$ that there is no major percolation, even though ice layers of several centimeters in thickness can be seen in cores at certain low-altitude stations.

The mean accumulation at different sites, as a function of their distance from point A (orthogonal 


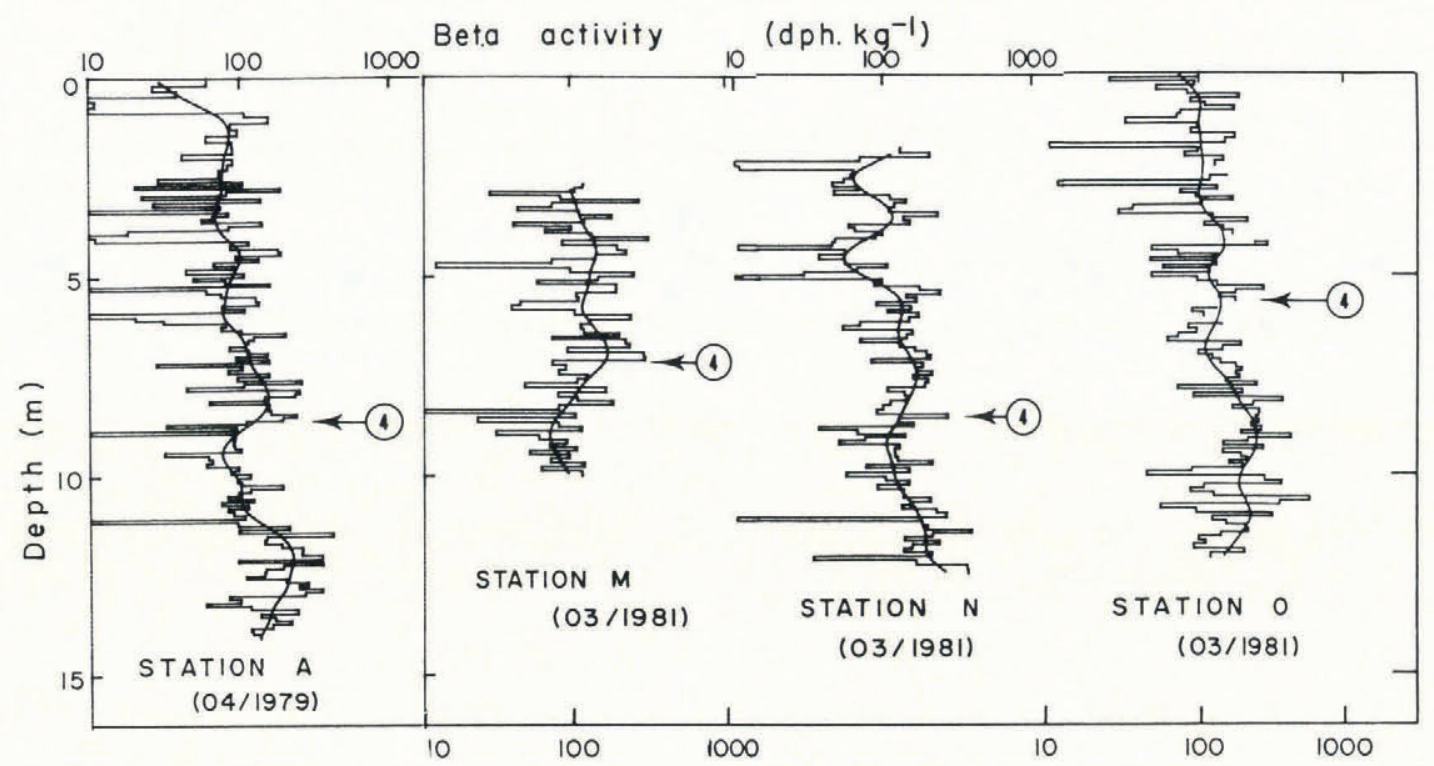

Fig. 4. Beta-radioactivity versus depth for stations $A, M, N$, and $O$.

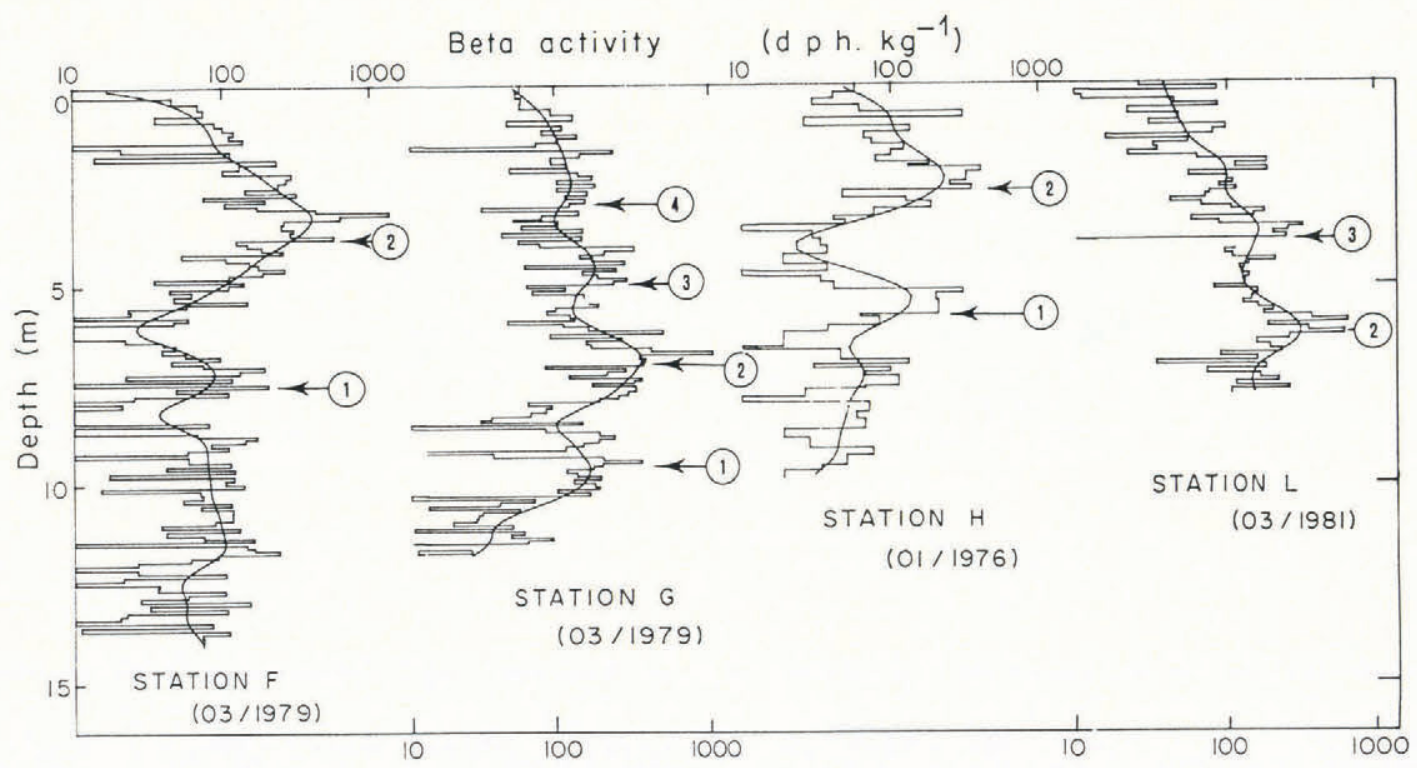

Fig. 5. Beta-radioactivity versus depth for stations $F, G, H$, and $L$.

projection along the $\mathrm{AL}$ axis), fits a straight line (correlation coefficient $=0.95$, excluding Mount Haddington). Over a distance of less than $20 \mathrm{~km}$, the mean accumulation rates decrease by a factor of 4 (Fig. 7). Only the summit dome of the ice cap deviates significantly from this average straight line and shows a major accumulation deficit which can be accounted for by the intense wind erosion occurring at this particular site where accumulation variations of $1-7$ from one year to another were detected (Aristarain, 1980). Our measurements appear to indicate that the geographic distribution of accumulation values is influenced by the south-westerly winds. The atmospheric disturbances carried by these winds likely condense rapidly when they reach the ice cap.

Moreover, this particular accumulation distribution would appear to be the reason why we found no relationship between its values and the firn temperatures, as has been observed for other Antarctic regions (Young and others, 1982).

At sites $D$ and $G$, the comparison of the mean accumulation rates since 1965 are about $50 \%$ and $40 \%$, respectively, greater than those for the period 1955-65, which agrees with the increase in Antarctic precipitation as pointed out by Pourchet and others (1983).

2. Field measurements have shown that the firn temperature at a depth of $10 \mathrm{~m}$ is close to the mean annual temperature at the surface for values greater than about $-35^{\circ} \mathrm{C}$ in areas where there is no substantial surface melting (Loewe, 1970).

In the case of surface snow melt, the heat of refreezing can lead to considerable differences (several deg) between the mean temperatures at the surface and in the firn (Paterson, 1981). This accounts for the higher temperature $\left(\simeq 1{ }^{\circ} \mathrm{C}\right)$ of the firn at Mount Haddington with respect to Dalinger Dome (Fig. 2), in spite of its higher altitude $(50 \mathrm{~m})$. A relatively high degree of snow melt has in fact been found on the summit dome (Aristarain, 1980). This situation must also exist to some extent at lower stations, since layers of ice were sometimes found.

We can now estimate the altitudinal lapse-rate (deg/ $100 \mathrm{~m}$ ) on James Ross Island, using our measurements of altitude and temperature. The gradient found is $-0.58 \mathrm{deg} / 100 \mathrm{~m}$ (correlation coefficient $=0.85$ when considering, in Table I, the 1981 temperature values for 


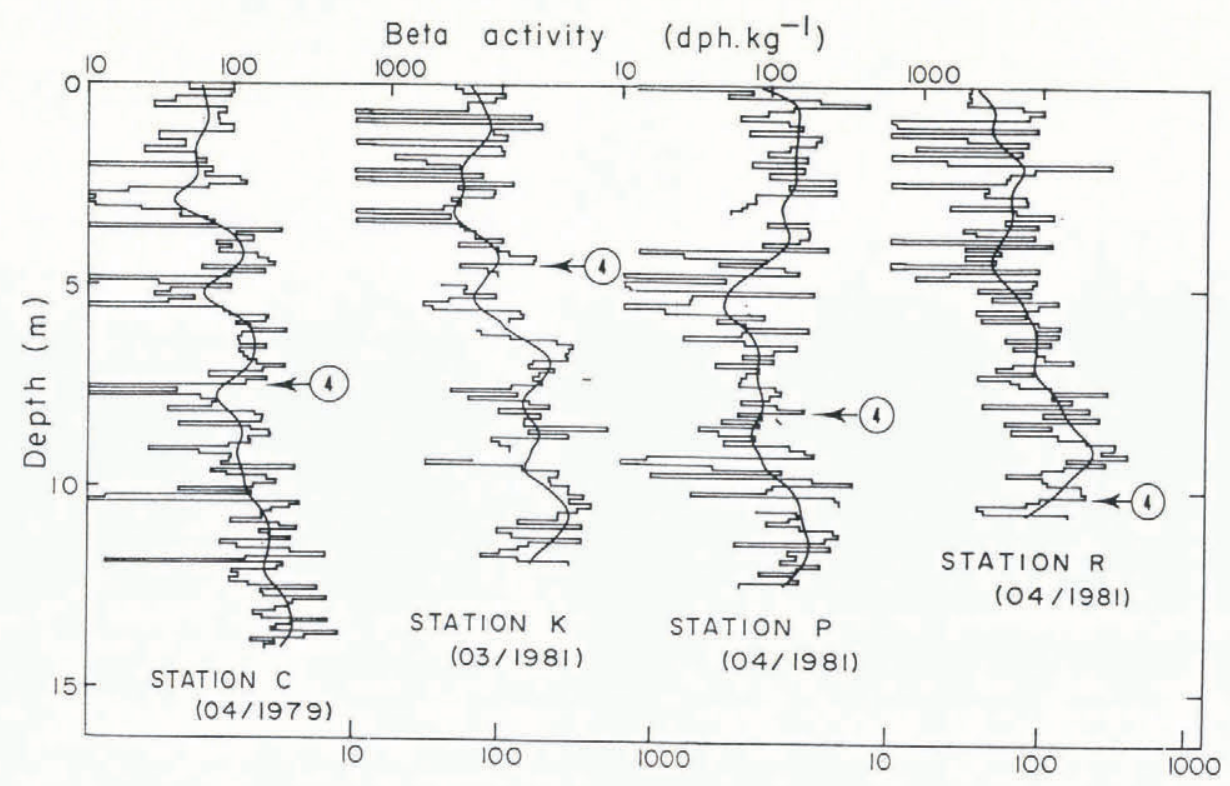

Fig. 6. Beta-radioactivity versus depth for stations $C, K, P$, and $R$.

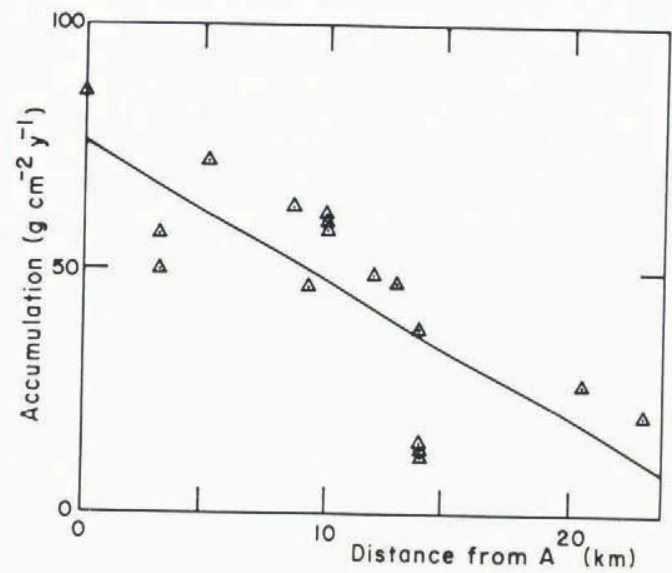

Fig. 7. Accumulation versus distance from station $A$ (orthogonal projection along $A L$ axis).

Dalinger Dome and Mount Haddington). This value is in good agreement with the value calculated by Reynolds (1981): $-0.57 \mathrm{deg} / 100 \mathrm{~m}$ for the Antarctic Peninsula.

The western and eastern regions of the Antarctic Peninsula have very different climatic characteristics, with maritime and continental regimes, respectively (Schwerdtfeger, 1970; Martin and Peel, 1978).

Figure 8 shows temperature versus altitude normalized to lat. $70^{\circ} \mathrm{S}$. for each region, as obtained by Reynolds (1981), with the points representing our stations on James Ross Island. We used the normalization coefficient given by Reynolds (1981) for the western part of the Antarctic Peninsula: $-0.77 \mathrm{deg} / \mathrm{degree}$ of latitude; the use of the coefficient for the eastern part of the Antarctic Peninsula ( $-0.85 \mathrm{deg} / \mathrm{deg}$ ree of latitude) would shift these points by -0.45 deg. In both cases, Figure 8 shows the predominantly western climatic character on the upper part of the James Ross Island ice cap, even though it is located on the eastern side of the Antarctic Peninsula. This fact, which agrees with the west coast change in temperature regime after 1970 (Schwerdtfeger, 1976), and the isotope trend at James Ross Island (Aristarain and Delmas, 1981) may be due to the influence of the prevailing westerly winds north of about lat. $65^{\circ}$ S., as reported by Schwerdfeger (1975). However, the strong winds from the south (south-west in the north of the Antarctic Peninsula), characteristic of the eastern climatic regime (Schwerdtfeger, 1975) and

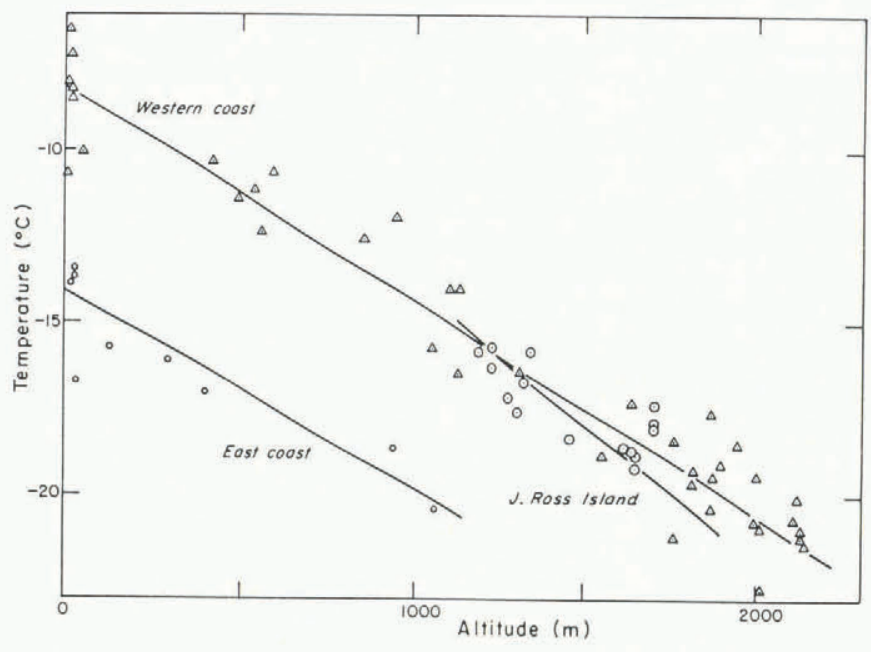

Fig. 8. Regression of $10 \mathrm{~m}$ temperature versus altitude, normalized to lat. $70^{\circ} \mathrm{S}$.

which affect James Ross Island and appear to dominate the distribution of accumulation on the ice cap, demonstrate the existence of a component of this regime. The isotope study carried out on Dalinger Dome supports this finding (Aristarain and others, 1986).

\section{CONCLUSIONS}

The snow accumulation has been deduced from wellknown radioactivity peaks, including the 1969 and 1974 peaks as new Antarctic Peninsula references. The snowaccumulation rates at 12 sites, located between 1190 and $1690 \mathrm{~m}$ in altitude on the James Ross Island ice cap, have provided an indication of the intensity and geographic distribution of precipitation on this part of the ice cap.

Firn temperatures at the different sites have enabled the estimation of the altitudinal lapse-rate for the study area. This gradient agrees well with that measured for the Antarctic Peninsula as a whole (Reynolds, 1981).

The temperatures at the various stations considered (after correction to lat. $70^{\circ} \mathrm{S}$.) confirm a predominantly western climatic character for the upper part of the ice cap in spite of its location to the east of the Antarctic Peninsula. However, the south-westerly winds, which appear to dominate the geographic distribution of precipitation, demonstrate the existence of an eastern climatic component. 


\section{ACKNOWLEDGEMENTS}

We are very grateful to the Instituto Antártico Argentino and the Fuerza Aerea Argentina for logistic work, and the French Centre National de la Recherche Scientifique and Ministère des Affaires Etrangères for financial support.

\section{REFERENCES}

Aristarain, A.J. 1980. Etude glaciologique de la calotte polaire de l'Ile James Ross (Péninsule Antarctique). Grenoble, CNRS-Laboratoire de Glaciologie et Géophysique de l'Environnement. (Publication 322.)

Aristarain, A.J., and Delmas, R. 1981. First glaciological studies on the James Ross Island ice cap, Antarctic Peninsula. Journal of Glaciology, Vol. 27, No. 97, p. 371-79.

Aristarain, A.J., and others. 1986. Past Antarctic Peninsula climate (1850-1980) deduced from an ice core isotope record, by A.J. Aristarain, J. Jouzel, and M. Pourchet. Climatic Change, Vol. 8, No. 1, p. 69-89.

British Antarctic Survey. 1974. British Antarctic Survey topographic map. Series BAS 250, Sheet $S Q \quad 21-22 / 1$ (extended). Edition 1. London, Directorate of Overseas Surveys.

Crozaz, G. 1969. Fission products in Antarctic snow, an additional reference level in January 1965. Earth and Planetary Science Letters, Vol. 6, No. 1, p. 6-8.

Delmas, R., and Pourchet, M. 1977. Utilisation de filtres échangeurs d'ions pour l'étude de l'activité $\beta$ globale d'un carottage glaciologique. [Union Géodesique et Géophysique Internationale. Association Internationale des Sciences Hydrologiques. Commission des Neiges et Glaces.] Symposium. Isotopes et Impuretés dans les Neiges et Glaces. Actes du Colloque de Grenoble, août/septembre 1975, p. 159-63. (IAHS-AISH Publication No. 118.)

Lambert, G., and others, 1977. Accumulation of snow and radioactive debris in Antarctica: a possible refined radiochronology beyond reference levels, by G. Lambert, B. Ardouin, J. Sanak, C. Lorius, and M. Pourchet. [Union Géodesique et Géophysique Internationale. Association Internationale des Sciences Hydrologiques. Commission des Neiges et Glaces.] Symposium. Isotopes et Impuretés dans les Neiges et Glaces. Actes du Colloque de Grenoble, août/septembre 1975, p. 146-58. (IAHS-AISH Publication No. 118.)

Loewe, F. 1970. Screen temperatures and $10 \mathrm{~m}$ temperatures. Journal of Glaciology, Vol. 9, No. 56, p. 263-68.

Martin, P.J., and Peel, D.A. 1978. The spatial distribution of $10 \mathrm{~m}$ temperatures in the Antarctic Peninsula. Journal of Glaciology, Vol. 20, No. 83, p. 311-17.

Paterson, W.S.B. 1981. The physics of glaciers. Second edition. Oxford, etc., Pergamon Press. (Pergamon International Library.)

Petit, J.R., and others. 1982. A detailed study of snow accumulation and stable isotope content in Dome C (Antarctica), by J.R. Petit, J. Jouzel, M. Pourchet, and L. Merlivat. Journal of Geophysical Research, Vol. 87, No. C6, p. 4301-08.

Picciotto, E., and Wilgain, S. 1963. Fission products in Antarctic snow, a reference level for measuring accumulation. Journal of Geophysical Research, Vol. 68, No. 21, p. 5965-72.

Pinglot, J.F., and Pourchet, M. 1979. Low-level beta counting with an automatic sample changer. Nuclear Instruments and Methods, Vol. 166, No. 3, p. 483-90.

Pourchet, M., and others. 1983. Some meteorological applications of radioactive fallout measurements in Antarctic snows, by M. Pourchet, J.F. Pinglot, and C. Lorius. Journal of Geophysical Research, Vol. 88, No. C10, p. 6013-20.

Reynolds, J.M. 1981. The distribution of mean annual temperatures in the Antarctic Peninsula. British Antarctic Survey Bulletin, No. 54, p. 122-33.

Schwerdtfeger, W. 1970. The climate of the Antarctic. (In Orvig, S., ed. Climates of the polar regions. Amsterdam, etc., Elsevier, p. 253-355. (World Survey of Climatology, Vol. 14.))

Schwerdtfeger, W. 1975. The effect of the Antarctic Peninsula on the temperature regime of the Weddell Sea Monthly Weather Review, Vol. 103, No. 1, p. 45-51.

Schwerdtfeger, W. 1976. Changes of temperature field and ice conditions in the area of the Antarctic Peninsula. Monthly Weather Review, Vol. 104, No. 11, p. 1441-43.

Young, N.W., and others. 1982. Accumulation distribution in the IAGP area, Antarctica: $90^{\circ} \mathrm{E}-150^{\circ} \mathrm{E}$, by N.W. Young, M. Pourchet, V.M. Kotlyakov, P.A. Korolev, and M.B. Dyugerov. Annals of Glaciology, Vol. 3, p. 333-38. 